ISSN: 2637-6679

DOI: $10.32474 /$ RRHOAJ.2018.01.000106

\title{
Nursing, Work and Mental Illness
}

\author{
Jose Dionisio de Paula Junior* \\ Postdoctoral Researcher in Occupational Safety, Brazil
}

Received: 製 February 05, 2018; Published: 孻 February 13, 2018

*Corresponding author: Jose Dionisio de Paula Junior, Postdoctoral Researcher in Occupational Safety, Federal University of Vicosa (UFV), Minas Gerais State, Brazil

\section{Introduction}

The worker's health is a public health whose object of study and intervention the relationship between work and health, which establishes a control of hazards to worker health. Thus, the term occupational health the body of knowledge from different disciplines such as Occupational Health Nursing, Public Health, Medicine, Occupational Medicine, Sociology, Social Epidemiology, Engineering, Psychology, among many others, which together with the scientific knowledge on occupational health establishes a new way of understanding the relationship between health and work. The work is a transformative activity of reality that provides the conditions for survival and fulfillment of the worker. Through actions, the product of their labor, the human being realizes his life as a project, recognizes its ontological condition, embodied and expressed their dependence and power over nature, producing the material, cultural and institutional resources that constitute its environment [1].

In this sense, the work can be approached in at least five different dimensions:

a. concrete - related to technology and material conditions in which it is exercised;

b. management - related to the way it is planned, organized, directed and controlled;

c. socioeconomic - referring to the social structure in its economic, legal and political levels;

This work is licensed under Creative Commons Attribution 4.0 License

To Submit Your Article Click Here : Submit Article

DOI: $10.32474 /$ RRHOAJ.2018.01.000106 d. ideological - referring to the values associated with the work that predominate in society;

e. Symbolic - referring to the subjective aspects of each individual.

In this context, the work should be a source of pleasure, since, through it, the worker is subject and recognizes its importance to the survival of other human beings. The relationship between labor and physical illness is known, long ago, in the scientific realm. However, the perception that the work can generate subtler ways, but no less serious, suffering and mental illness, is still a new concept. The absence of specific symptoms makes the search for care happens after the expiration of the disease. This is because the illness at work is valued and recognized only when it comes in the form of physical manifestation [2]. The relationship between labor and physical illness is known, long ago, in the scientific realm. However, the perception that the work can generate subtler ways, but no less serious, suffering and mental illness, is still a new concept. The absence of specific symptoms makes the search for care happens after the expiration of the disease. This is because the illness at work is valued and recognized only when it comes in the form of physical manifestation.

\section{References}

1. Paula Júnior J D (2014) Salud de lostrabajadoresen la indústria: intervenciónmultidisciplinario, Germany.

2. Dejours CA (2007) Loucura do trabalho: estudo de psicopatologia do trabalho $5^{\text {th }}$ edn. São Paulo: Cortez- Oboré, Brazil.

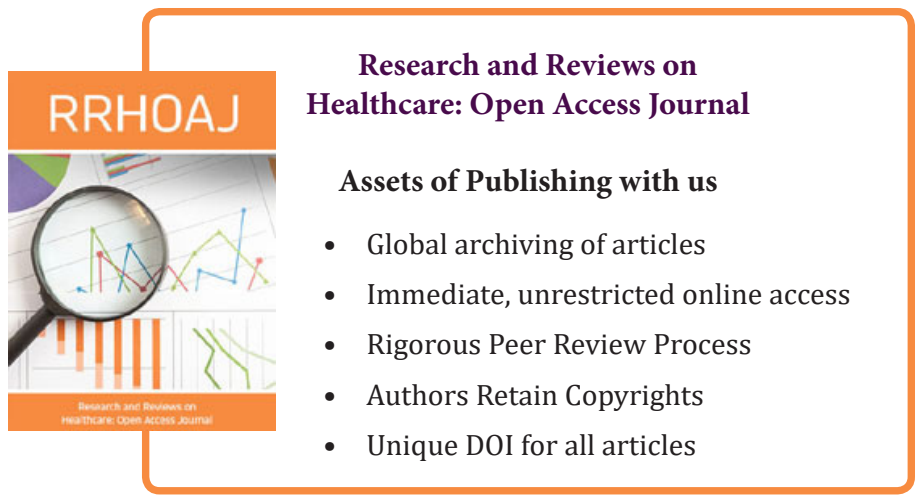

